\title{
Conceptual advances on global scale assessments of vulnerability: Informing investments for coastal populations at risk of climate change
}

\author{
Comte Adrien ${ }^{1,{ }^{*}}$, Pendleton Linwood H. ${ }^{1,2,3,4}$, Bailly Denis ${ }^{1}$, Quillérou Emmanuelle ${ }^{1,5}$
}

${ }^{1}$ Univ Brest, Ifremer, CNRS, UMR 6308, AMURE, IUEM, 29280 Plouzane, France

2 Duke University, Durham, NC, USA

${ }^{3}$ Global Science, World Wildlife Fund, Washington, DC, United States

${ }^{4}$ Global Change Institute, University of Queensland, Brisbane, QLD, Australia

* Corresponding author : Adrien Comte, email address : adrien.comte@univ-brest.fr

\begin{abstract}
:
Since the 1990s, the Intergovernmental Panel on Climate Change (IPCC) has used global assessments of vulnerability to inform investment and action against the effects of climate change. Beyond the IPCC, others have undertaken global assessments to understand the vulnerability of coastal areas to climate change. Eight global vulnerability assessments are compared to understand similarities and differences in their results and the metrics used to construct a vulnerability index. Variations in objectives, conceptualizations of vulnerability, operationalization of the concepts, scope and depth of data drawn upon lead to contradictory rankings of priority areas for climate action between assessments. The increased complexity and scope of indicators make it difficult to untangle the root causes of such differences in rankings. It is also difficult to identify the degree to which climate change influences vulnerability rankings compared to other factors such as local environmental conditions and the capacity of populations to deal with environmental change. The way to undertake global assessments needs to be reshaped to better inform planning of international development along different objectives. Global level assessments need to be simplified and harmonized to better isolate the impact of climate change specific drivers. Decision-makers would make better use of such global assessments as scoping studies rather than expect comprehensive and robust priorities for investment. Such scoping studies can help target locations where supplementary, in-depth local analyses need to be conducted. At the local level, the possibility to collect context-specific information, particularly on adaptive capacity, allows the robust assessment of vulnerability.
\end{abstract}

Keywords : Climate change, Vulnerability, Marine and coastal areas, Prioritizing investments, Global assessments, Conceptual frameworks 


\section{Global level assessments, climate change impacts on coastal populations and informed action}

Climate change is expected to have severe adverse effects on marine and coastal ecosystems and human activities which depend on them (Allison \& Bassett, 2015; Gattuso et al., 2015), thus calling for better identification of areas at particular risk to mitigate their impacts. Long-term changes, such as sea-level rise, ocean acidification, and changes in sea surface temperature are expected to put millions of people and billions of dollars' worth of economic sectors at risk (O. Hoegh-Guldberg et al., 2014). Countries across the globe are not equally vulnerable to, and will not be equally impacted by, the wide-ranging effects of climate change, the large majority of which is expected to be negative. Understanding which countries are most vulnerable to the adverse effects of climate change is important, firstly for equity 
reasons (Smit \& Pilifosova, 2003; Wolff et al., 2015), and secondly to inform investments in research and action including adaptation planning and capacity building (Cutter, Boruff and Shirley 2003).

This issue is raised in article 4.4 of the United Nations Framework Convention on Climate Change (UNFCCC). Article 4.4 states that developed countries shall "[...] assist the developing country parties that are particularly vulnerable to the adverse effects of climate change in meeting costs of adaptation to those adverse effects" (United Nations, 1992). The same mandate was given to global financial institutions such as the Green Climate Fund (GCF) and the Adaptation Fund. For instance, the GCF "[aims] for a floor of fifty per cent of the adaptation [funding] allocation for particularly vulnerable countries, including least developed countries (LDCs), small island developing States (SIDS) and African States" (GCF, 2014, Decision B.06/06). In addition, international development targets such as the Sustainable Development Goals (SDGs) have reinforced the demand for scientific assessments at the global level that can help inform climate and development investment and action. The international climate negotiations embraced the idea of vulnerability. The scientific community is attempting to provide input to climate negotiations, but some argue that identifying vulnerable countries is a political process (Klein, 2009). For instance, the Climate Vulnerable Forum was founded to create a coalition and build capacity of countries that identify as vulnerable in international negotiations.

Global level indicator-based vulnerability assessments have become very popular in the hope of using them as tools to identify "developing country parties that are particularly vulnerable to the adverse effects of climate change" to receive help from countries that have the means to do so, in the form of financial transfers in order to "[meet the] costs of adaptation to those adverse effects" (United Nations, 1992). The Intergovernmental Panel on Climate Change (IPCC) was an early adopter of global level indicator-based vulnerability assessments to identify vulnerable places in particular need of assistance to combat climate change. They aimed at communicating the seriousness of climate change more effectively with spatial analyses and maps. Vulnerability assessments are used by the IPCC to communicate places needing investment and action the most.

Assessing future threats of global environmental change on ocean and coastal socio-ecological systems is important for the sustenance of economies and livelihoods. Vulnerability assessments developed by the research community rely on a scientifically sound understanding of the impacts of climate change on physical, ecological and social systems (Adger, 2006; Cutter et al., 2003; Polsky, Neff, \& Yarnal, 2007; Schröter, Polsky, \& Patt, 2005; Turner et al., 2003). They draw from a range of academic disciplines including oceanographic, ecological, and social sciences. They use different methods but usually construct composite indicators to be able to rank countries (Tonmoy \& Hinkel, 2014; Wolf, Hinkel, Bisaro, \& Klein, 2012). However, the current lack of understanding of the mechanistic relationships between global changes and socio-economic impacts is hindering the development and establishment of comprehensive and consistent approaches by the marine science community. It has been argued that using the IPCC vulnerability framework could help the marine science community move forward to better characterize impacts of climate change on the marine environment and guide decision-makers (Mathis et al., 2015). 
Many studies coming from the research community as well as international organizations and NonGovernmental Organizations (NGOs) have attempted to rank countries based on their vulnerability to climate change. In order to do so, composite indexes have been built to establish these vulnerability assessments. There is no unified approach to global indicator-based vulnerability assessment which has resulted in a variety of applications, even for those focused specifically on marine and coastal applications, and a drive for such analyses to become more data intensive and "comprehensive" over time (Füssel \& Klein, 2006). Methodologies and results vary greatly across these assessments, which have triggered much debate within the research community on using indicator-based vulnerability assessments at the global level. For example, Hinkel (2011) argues that vulnerability assessment was originally designed and is best suited for application at the local level and not the global level.

Acknowledging that different local vulnerability assessments can have different goals which inform the types of methods and appropriate data (Preston, Yuen, \& Westaway, 2011), there are inherent problems in conducting vulnerability assessments at the global level. The assumptions and final scores used for prioritizing countries produced by such assessments make it difficult to understand the main drivers of climate vulnerability and thus identify the main opportunities for relevant climate-related investment. Methodologies are rarely explicit, and aggregating all data used into a single score degrades complexity and quality of information. The challenges that confront the global level application of vulnerability assessments for use in targeting climate-related investment include:

- a lack of harmonized conceptualization of vulnerability and associated concepts, in particular impact and adaptive capacity, in addition to how these concepts are operationalized in practice,

- an ever expanding number of variables used for such assessments, many of which are not available reliably at the global level, resulting in increased complexity of analysis and combination of very different metrics together which make it difficult to isolate climate impacts on populations from other factors,

- a lack of consideration of the costs of action in addition to climate vulnerability and impacts.

Section 2 of this paper summarizes briefly the current use of vulnerability assessments to understand impacts of climate change on coastal populations, describing the concepts put forward in different IPCC reports. Section 3 is an analysis of methods and results from a selection of the most cited global vulnerability assessments on marine and coastal systems in order to highlight limitation of vulnerability assessments conducted at the global scale. Section 4 proposes a two-tier approach as a way forward to provide guidance for future vulnerability assessments on coastal and marine issues.

\section{Contrasted conceptualizations of vulnerability and associated concepts}


Vulnerability is a concept that is intuitively understandable and simple because it is used in many everyday life contexts: one can be vulnerable to diseases, attacks etc. This concept allows for integration of physical, ecological, and human impacts of and adaptability to climate change. The concept emerged in its current form in relation to environmental studies in the 1980s (Timmerman, 1981), disaster risk reduction at the local level in the 1990s (e.g. Weichselgartner, 2001), political ecology and resilience in the 2000s (Eakin \& Luers, 2006) and has evolved over time to be used by interdisciplinary research on a number of topics including climate change (Turner et al., 2003). During this evolution, climate change vulnerability assessments have become more complex, building from impact assessments to include non-climate drivers (of environmental or socio-economic nature) and adaptation responses (Füssel \& Klein, 2006). However, there is no consistent definition nor conceptualization of vulnerability yet (Adger, 2006). Vulnerability research efforts are currently focusing on developing independent vulnerability approaches and indexes to test their relevance and applicability for adaptation planning. The vulnerability concept lacks an operational definition and measurement for consistent practical applications (Adger, 2006), because it is difficult to choose among competing approaches or to understand their differences (O'Brien et al., 2007). Ten years later there is not much evidence of significant improvement in this area, which has lead to tensions in international climate negotiations (Oculi \& Stephenson, 2018).

The evolving nature of the definition and analytical framework used for assessing vulnerability can be best illustrated through the evolution of the framework used by the IPCC between 2001 and 2014 (Figure 1. a,b). In the IPCC Third Assessment Report of 2001, vulnerability was defined as "a function of the character, magnitude and rate of climate variation to which a system is exposed, its sensitivity and its adaptive capacity" (Schneider and Sarukhan, 2001, p.92, Figure 1.a). In the Fifth Assessment Report -and already in the IPCC Special Report on EXtreme events and disasters (IPCC, 2012), the definition of vulnerability was revised to best capture systems complexity: "the propensity or predisposition to be adversely affected. Vulnerability encompasses a variety of concepts and elements including sensitivity or susceptibility to harm and lack of capacity to cope and adapt" (Oppenheimer et al., 2014, p.1046, Figure 1.b). This evolution of thinking was not followed by guidelines to operationalize this new conceptual framework, so it is left to different disciplines to assess and integrate the complex facets of vulnerability as they are described by the IPCC. To add to the challenge, the vulnerability framework is applied to a variety of perspectives in the IPCC reports (vulnerability of ecosystems, populations, the economy), adding confusion over the message conveyed.

Figure 1 here.

Even though conceptualizations differ for the definition of vulnerability, the core of the vulnerability framework remains relatively unchanged and can be boiled down to its components of hazard, exposure, sensitivity, adaptive capacity and vulnerability (Figure 2.). Key differences between the frameworks lie in the way the relationship between vulnerability and the other factors is formalized, and the feedbacks and actions that influence and are influenced by vulnerability - namely adaptation, mitigation, and 
governance. This flexibility in the framework makes the vulnerability concept well suited to analysis at the local level, where more context specific information is available (Hinkel, 2011). It makes however the concept more difficult to use at the global level in a consistent way, which would require more of a 'blueprint' approach if it is to guide investments across different types of risks and social contexts with some degree of equality and comparability.

Figure 2 here.

\title{
3. What do global vulnerability assessments actually reveal: understanding conflicting vulnerability rankings from climate change impacts on coastal human populations
}

\begin{abstract}
A number of global indicator assessments, applied to marine resources, have been conducted by academics (Allison et al., 2009; Barange et al., 2014; Blasiak et al., 2017; Cooley et al., 2012; Halpern et al., 2012; Hughes et al., 2012; Monnereau et al., 2017) and Non-Governmental Organizations (Beck, 2014; Burke, Reytar, Spalding, \& Perry, 2011; Harrould-Kolieb, Hirshfield, \& Brosius, 2009; Huelsenbeck \& Vorpahl, 2012) to assess ocean health and the specific risks faced by marine ecosystems and the people that depend upon them. Eight of these 11 global vulnerability assessments are compared here. Three papers are not taken into account because of specific focus on mollusks (Cooley et al., 2012) or because they base their analysis on a paper already reviewed here (Monnereau et al. 2017; Blasiak et al., 2017). The selection of the international literature reviewed here includes seminal papers focusing on coastal and marine vulnerability at the global scale, totalizing 2509 citations according to Google Scholar, and is not intended as a systematic review of the scientific effort on vulnerability assessments. The analysis of this literature focuses on the methods and results published by global vulnerability assessments in order to highlight limitations for applications at the global scale.

Each has appropriated and redefined the core concepts of the approach differently (Table 1). All of these studies have the aim to measure the vulnerability of societies to changes in the ocean, whether it is fisheries, coral reefs, or a range of ecosystem services provided by the ocean. Most assessments define vulnerability as a combination of exposure, sensitivity, and adaptive capacity and measure it using indicators that fit in these three categories. The formulae used to calculate vulnerability itself vary across these studies. Four of the studies calculate vulnerability as a function of exposure, sensitivity, and adaptive capacity. Two studies only measure exposure and sensitivity. The ocean health index measures different but related concepts, including current state, trends, pressures, and resilience. Since the introduction of a new definition of vulnerability by the IPCC in 2012, one report (Beck, 2014) uses this
\end{abstract}


new definition, where risk is a function of exposure and vulnerability, and vulnerability is a function of sensitivity and adaptive capacity.

Table 1 here.

Even when definitions are common, the indicators and corresponding datasets used to measure hazard, exposure, sensitivity, adaptive capacity, mostly in relation to available data and specific focus of these studies. A recent analysis of ten global climate vulnerability assessments ( 6 of which are also analysed here, the other four being general vulnerability assessments not targeted at coastal and marine systems) found important methodological differences across studies: a difference in the number of countries taken into account, the use of socio-economic indicators not scaled to population size, the small number of indicators used and the lack of redundancy test for the selected indicators (Monnereau et al., 2017). While using similar basic frameworks, the existing global-level studies of the climate impacts to coastal populations use different indicators composed of multiple variables to determine exposure, sensitivity and adaptive capacity. For instance, these studies differ in terms of the hazards they take into account, exposed populations, dependence of livelihood and infrastructure, and capacity to deal with climate change. Starting from the same framework developed by Allison et al. (2009) to study the vulnerability of marine fisheries, two groups of researchers introduced different methodological improvements and choice of indicators that have led to the conclusion that LDCs are more vulnerable in the first case (Blasiak et al., 2017) whilst SIDS are more vulnerable in the other (Monnereau et al., 2017).

As a result of different definitions, conceptual representations, and indicators used in global assessments of coastal and marine risks, very different rankings of priorities for countries at risk have been established. Table 2 shows a large number of different countries that appear in the 'top 10' most vulnerable for the eight global assessments. Of these, $53 \%$ of countries (or 42 out of 79 ) appear in the top 10 of only one of the reports, suggesting more difference than coherence. No country is found in the top 10 of all of the reports and only two countries, Sierra Leone and the Philippines, are found in the top 10 of half the reports. This finding corroborates a previous comparison of national level studies that found great differences in indicators and countries ranking (Eriksen \& Kelly, 2007).

Table 2 here. 
The lack of consistent operational definition and measurement of vulnerability means it is difficult to discriminate between existing vulnerability approaches and identify the "right one" from a theoretical perspective. In an effort to be more comprehensive and to reflect the different abilities of coastal populations to deal with climate change, recent indicator-based global level assessments include coping and adaptive capacities. Multiple factors influence the capacity of coastal populations to respond to climate change, depending on the local socio-economic characteristics, multi-level governance, but also cultural norms and customs, and perceptions of risk (Cinner et al., 2018; Evans et al., 2016). Adaptive capacity is often the most complex component of vulnerability to understand, define, and collect data on because it is the most context-specific. Some empirical work suggests that global adaptive capacity indicators can be identified (Brooks, Adger, \& Kelly, 2005) but they so far reflect generic issues such as education and poverty that may be very important for development and well-being but not necessarily for dealing with sectoral impacts of climate change (Hughes et al., 2012). All but two of these studies include measures of capacity (Barange et al., 2014; Harrould-Kolieb et al., 2009).

Metrics of adaptive capacity used in the eight global vulnerability assessments were categorized into the five domains of adaptive capacity described in (Cinner et al., 2018). "Assets" include resources of different nature (economic, technological, environmental), "Flexibility" measures the diversity of possible options to adapt to climate change, "Organizations" describes governance and social cohesion, "Learning" captures the generation and utilization of knowledge, and "Agency" describes the ability of people and organizations to mobilize the other domains of adaptive capacity into action. Some assessments already use a similar way of categorizing their adaptive capacity metrics (Hughes et al., 2012). Others use different labels. For example in the Ocean Health Index, these metrics are found under the term social resilience. In other reports (Allison et al., 2009; Coasts at Risk; Reefs at Risk), categories include economy, health, education, and governance. When adaptive capacity categories are different from (Cinner et al., 2018), we use in-text justification of the choice of metrics to categorize them.

Similarities and differences can be found in the metrics used for measuring adaptive capacity in these assessments (Table 3). Assets and organization contain the most number of metrics. Agency metrics are the least commonly found across studies and is not consistently measured. Agency is a difficult concept to operationalize with quantitative measures. Measuring the empowerment and freedom of people and institutions to adapt and shape their livelihoods is a frontier of researcher, with few papers investigating barriers to adaptation (Barnett et al., 2015; Weichselgartner \& Kasperson, 2010). Metrics of assets and learning are consistent across the studies, with GDP per capita, life expectancy, and adult literacy rate being the most used metrics. In fact, these are the metrics found in the widely used Human Development Index (Sen, 1994), which raises issues of redundancy and more importantly relates to development policies and ideologies (McGillivray, 1991). Metrics of natural assets are also not consistent across studies. Organization is defined consistently, with global metrics available to characterize this concept, including the fisheries management effectiveness index developed by (Mora et al., 2009). However, different studies include a wide variety of other metrics besides fisheries management effectiveness to characterize organization. Flexibility metrics are all related to access to alternative sources of livelihood, but are measured inconsistently across studies. 
Table 3 here.

There are two immediate consequences of the use of adaptive capacity measures in these assessments. First, developed countries that face large potential impacts from climate change do not rank high - even though the value of needed adaptation related investment may be extremely large. Second, it becomes difficult to know, using final scores alone, whether a country with a high indicator score is due to vulnerability caused by climate change or inherent vulnerabilities caused by demographic, political, and social factors. The recent developments in vulnerability assessments attempt to include more targeted measures of adaptive capacity that are not yet rooted in empirical evidence. Causal relationships between adaptive capacity and impacts in social-ecological systems are still lacking (Breshears, LópezHoffman, \& Graumlich, 2010; Scheuer, Haase, \& Meyer, 2011).

A lack of an agreed definition, a lack of standard measurements of vulnerability across studies and an ambiguous use of the concept for multiple perspectives (what/who is vulnerable to what changes) have partly impaired the establishment of clear unambiguous global assessments. It is therefore of little surprise that such global assessments have, in turn, not been able to help set up clear priorities for climate investment and action.

\section{A two-tiered approach for global assessment to inform climate investment and action}

To avoid the challenges described in section 2 and section 3 and to move towards a more transparent approach to global indicator assessments that can be used to identify climate action, a simplification and harmonization of assessments is needed. The goal of global level assessments should remain to understand the impacts of climate change at the global level for coastal human populations, but the methodology to do so must evolve. Specifically, a two-tiered approach is suggested for classifying existing studies to better identify common elements, and guide further global analysis (Figure 3.):

1. GLOBAL LEVEL IMPACT ASSESSMENTS (first tier): Global level assessments should focus on simplified and more standardized scoping studies for which good global data are available. These simpler approaches should link climate change directly to impact, be limited to impacts, and not include measures of adaptive capacity so as to clearly separate development issues from threats driven by climate change. A focus on global-level impact assessments can help identify countries where:

a. climate action may be warranted (mitigation, adaptation or other),

b. additional, finer scaled vulnerability assessments may provide crucial information to set up appropriate policy action, and 
c. monitoring and science may yield socially relevant results.

The scores used to rank countries could be presented by impact or as a summary measure of how highranked countries scored across the impacts considered. The impacts of climate change are direct pathways through which the effects of climate change will adversely affect species, ecosystems, and socio-economic systems. Climate effects include ocean warming, acidification, sea-level rise, changes in extreme weather events, deoxygenation, modification of currents, and changes in salinity (HoeghGuldberg et al., 2014). Examples of such studies include impacts of climate effects on economic sectors in general (Allison \& Bassett, 2015; Weatherdon et al., 2016), on fisheries (Barange et al., 2014; Cheung et al., 2009, 2010), on ecosystem services (Pendleton et al., 2016), or on global ecosystems (HoeghGuldberg \& Bruno, 2010). Global-level scoping analyses based on impacts are meant to guide more refined and more data-intensive local level analyses, but do not aim to replace such local level analyses. Ideally, such analyses are accompanied by a global scale analysis of technical, economic and social costs of action for comparison to potential benefits from impact mitigation and adaptation. They should also be accompanied by analysis of the equity and justice repercussions of the distribution of potential impacts (Wolff et al., 2015), which was partly the role of including adaptive capacity in vulnerability assessments.

2. LOCAL LEVEL ASSESSMENTS (second tier): The global scoping assessments should identify places where more comprehensive local level assessments can be conducted to identify concrete investment actions and the degree to which these places are vulnerable to climate change, including the socioeconomic and political factors influencing vulnerability.

At the local level, more refined, data-intensive analysis can be used to better understand local impacts of global and local changes and behaviors. Such analyses would include, but not be limited to, vulnerability assessments, and would help identify key environmental and ecological factors affecting human dependencies which are most impacted by climate change. At this level, the socio-economic and political factors influencing adaptive capacity can be identified and assessed in a vulnerability framework. There already exists a number of relevant local level assessments which have been successfully applied in developed and developing countries that could be better used to understand climate impacts and actions (e.g. Cinner et al. 2012; Ekstrom et al. 2015; Gupta et al. 2010).

Figure 3 here.

This two-tiered approach is a pragmatic way to make the most of available data, approaches and scientific methods to undertake meaningful assessments that can guide climate action and help prioritize efforts where most urgently needed. It also helps provide a global-level, transparent framework while keeping local flexibility for climate investment and action from the global down to the local level. Like vulnerability assessments, the approach combines natural and social sciences to understand the potential impacts on people of climate change, but it does so at levels that better match the social 
science concepts to the scale at which relevant data are available. The first tier allows for meaningful policy recommendations at the global level, while the second tier provides the needed flexibility in relation to changing spatial and human contexts.

Such a two-tiered approach still requires continued improvements in the quality and quantity of natural and social science data. While natural science data regarding climate, oceanography, corals and fisheries continues to improve, social human data lag behind, especially data about local fisheries, tourism and the built environment as well as preparedness, capacity to act and representations. There is a need for better data and science to be able to structure global-level assessments in a globally coherent and meaningful way, with a need for research and data collection efforts to be targeted accordingly.

The semantics used in the international policy arena are framed around the term "vulnerability" and are making it difficult to move past vulnerability assessments at the global scale. While assessing potential impacts instead of vulnerability at the global scale is important, targeting vulnerable countries is a policy agenda that may be hard to challenge (Klein, 2009). This even though current international funds are not necessarily targeting "vulnerable countries" which do not have the capacity to apply for funding (Tango International \& ODI, 2015).

The suggested way forward corresponds to taking a step back and adopts a simplified approach. Instead of trying to derive meaningful guidance from applying one tool at inappropriate scales of analysis (vulnerability assessments applied at the global level), a combination of scale-relevant tools could be applied. This would amount to shifting the emphasis from using tools at the global level to identify local impacts (i.e. the downscaling of global results to the local level) to using tools at the global level to identify potential local impacts and inform local analysis and appropriate action. It seems that this interfacing of a top-down approach and a bottom-up approach is gaining momentum in the design of new vulnerability assessments (Hobday et al., 2016; Mastrandrea, Heller, Root, \& Schneider, 2010; Wilby \& Dessai, 2010).

\section{Conclusion}

Current global vulnerability assessments are not able to fulfil their goal to give clear guidance towards the identification of vulnerable countries. Shortcomings include a lack of agreed definitions, concepts, and metrics to measure vulnerability. Adaptive capacity is particularly problematic to assess at the global scale. If they are to be useful to decision-makers with a global reach, including Inter-governmental Organizations, Multi-lateral funds such as the Green Climate Fund and global NGOs, global level assessments should not be designed and applied as comprehensive studies but rather as scoping studies that focus clearly on the basic pathways that link climate change to impacts on people, without extending the analysis to determine overall vulnerability which is context specific. These global level "impact assessments" then should be supplemented by more refined local level vulnerability assessments and analyses of costs of action to provide information useful to climate action and investment from the global down to the local level. 
The first tier of the two-tiered approach could be useful to identify all countries that are likely to experience large direct or indirect impacts from climate change. If applied to a pool of recipient countries alone (i.e. developing countries under Article 4.4 of the UNFCCC receiving international transfers), such a tier could be used to identify places where foreign assistance to meeting the costs of adaptation under the UNFCCC may be most useful and improve efficiency of international climate funding. The second tier could be used by developed and developing countries alike to inform more finetuned context-appropriate investment within countries, and not just international transfers. This second tier can consider different types of action, including climate change action but not exclusively, and different investment options into mitigation, adaptation, governance and science. It can broaden stakeholder engagement at the local level to include civil society and other parties that could improve country ownership and improve effectiveness of climate action (Brown, Polycarp, \& Spearman, 2013; Lebel et al., 2006). Global mechanisms need to use objective criteria to prioritize investments and actions and vulnerability assessments will remain an important tool to do so.

In addition to the two tiers proposed here, parallel but separate analyses of costs of action including technical, social and economic factors should be conducted at multiple scales. There are enormous gaps in terms of finance, technology, and knowledge for adaptation -particularly in developing countries(UNEP, 2014), but a detailed estimate of investment needs for coastal populations is lacking. Vulnerability and impact assessments are not sufficient to identify and appraise actions to respond to climate change (Tulloch et al., 2015). The combination of the two-tiered approach and analyses of costs of action should provide necessary information for informed climate investment and action.

\section{ACKNOWLEDGMENTS}

This manuscript was developed after an earlier note published in OCEAN AND CLIMATE, 2015 - Scientific Notes.www.ocean-climate.org, 116 pages. This research was possible thanks to a grant from the Prince Albert II of Monaco Foundation and a grant from the Region of Brittany. It was also supported by the "Laboratoire d'Excellence" LabexMER (ANR-10-LABX-19) and co-funded by a grant from the French government under the program "Investissements d'Avenir". This research was also supported by the French National Initiative for Coral Reefs (IFRECOR) program. We are thankful to J. Ekstrom for providing helpful comments.

\section{REFERENCES}

Adger, W. N. (2006). Vulnerability. Global Environmental Change, 16(3), 268-281. http://doi.org/10.1016/j.gloenvcha.2006.02.006

Allison, E. H., \& Bassett, H. R. (2015). Climate change in the oceans: Human impacts and responses. Science, 350(6262), 778-782. http://doi.org/10.1126/science.aac8721

Allison, E. H., Perry, A. L., Badjeck, M.-C., Neil Adger, W., Brown, K., Conway, D., ... Dulvy, N. K. (2009). Vulnerability of national economies to the impacts of climate change on fisheries. Fish and 
Fisheries, 10(2), 173-196. http://doi.org/10.1111/j.1467-2979.2008.00310.x

Barange, M., Merino, G., Blanchard, J. L., Scholtens, J., Harle, J., Allison, E. H., ... Jennings, S. (2014). Impacts of climate change on marine ecosystem production in societies dependent on fisheries. Nature Climate Change, 4(February), 211-216. http://doi.org/10.1038/NCLIMATE2119

Barnett, J., Evans, L. S., Gross, C., Kiem, A. S., Kingsford, R. T., Palutikof, J. P., \& Pickering, C. (2015). From barriers to limits to climate change adaptation: path dependency and the speed of change. Ecology and Society, 20(3), art5. http://doi.org/10.5751/ES-07698-200305

Beck, M. W. (2014). Coasts at risk - An assessment of coastal risks and the role of environmental solutions. Retrieved from http://www.crc.uri.edu/download/SUC09_CoastsatRisk.pdf

Blasiak, R., Spijkers, J., Tokunaga, K., Pittman, J., Yagi, N., \& ?sterblom, H. (2017). Climate change and marine fisheries: Least developed countries top global index of vulnerability. Plos One, 12(6), e0179632. http://doi.org/10.1371/journal.pone.0179632

Breshears, D. D., López-Hoffman, L., \& Graumlich, L. J. (2010). When ecosystem services crash: preparing for big, fast, patchy climate change. Ambio, 40(3), 256-263. http://doi.org/10.1007/s13280-0100106-4

Brooks, N., Neil Adger, W., \& Mick Kelly, P. (2005). The determinants of vulnerability and adaptive capacity at the national level and the implications for adaptation. Global Environmental Change, 15(2), 151-163. http://doi.org/10.1016/j.gloenvcha.2004.12.006

Brown, L., Polycarp, C., \& Spearman, M. (2013). Within Reach: Strengthening Country Ownership and Accountability in Accessing Climate Finance. World Resources Institute. Retrieved from http://www.wri.org/sites/default/files/ownership_and_accountability_final_paper.pdf

Burke, L., Reytar, K., Spalding, M., \& Perry, A. (2011). Reefs at risk Revisited. World Resources Institute. Washington, D.C.

Cheung, W. W. L., Lam, V. W. Y., Sarmiento, J. L., Kearney, K., Watson, R., \& Pauly, D. (2009). Projecting global marine biodiversity impacts under climate change scenarios. Fish and Fisheries, 10(3), 235251. http://doi.org/10.1111/j.1467-2979.2008.00315.x

Cheung, W. W. L., Lam, V. W. Y., Sarmiento, J. L., Kearney, K., Watson, R., Zeller, D., \& Pauly, D. (2010). Large-scale redistribution of maximum fisheries catch potential in the global ocean under climate change. Global Change Biology, 16(1), 24-35. http://doi.org/10.1111/j.1365-2486.2009.01995.x

Cinner, J. E., Adger, W. N., Allison, E. H., Barnes, M. L., Brown, K., Cohen, P. J., ... Morrison, T. H. (2018). Building adaptive capacity to climate change in tropical coastal communities. Nature Climate Change, 8(2), 117-123. http://doi.org/10.1038/s41558-017-0065-x

Cinner, J. E., McClanahan, T. R., Graham, N. a. J., Daw, T. M., Maina, J., Stead, S. M., ... Bodin, Ö. (2012). Vulnerability of coastal communities to key impacts of climate change on coral reef fisheries. Global Environmental Change, 22(1), 12-20. http://doi.org/10.1016/j.gloenvcha.2011.09.018

Cooley, S. R., Lucey, N., Kite-Powell, H., \& Doney, S. D. (2012). Nutrition and income from molluscs today imply vulnerability to ocean acidification tomorrow. Fish and Fisheries, 13(2), 182-215. http://doi.org/10.1111/j.1467-2979.2011.00424.x 
Cutter, S. L., Boruff, B. J., \& Shirley, W. L. (2003). Social vulnerability to environmental hazards. Social Science Quarterly, 84(2), 242-261. http://doi.org/10.1111/1540-6237.8402002

Eakin, H., \& Luers, A. L. (2006). Assessing the Vulnerability of Social-Environmental Systems. Annual Review of Environment and Resources, 31(1), 365-394.

http://doi.org/10.1146/annurev.energy.30.050504.144352

Ekstrom, J. A., Suatoni, L., Cooley, S. R., Pendleton, L. H., Waldbusser, G. G., Cinner, J. E., ... Portela, R. (2015). Vulnerability and adaptation of US shellfisheries to ocean acidification. Nature Climate Change, 5(3), 207-214. http://doi.org/10.1038/nclimate2508

Eriksen, S. H., \& Kelly, P. M. (2007). Developing credible vulnerability indicators for climate adaptation policy assessment. Mitigation and Adaptation Strategies for Global Change, 12(4), 495-524. http://doi.org/10.1007/s11027-006-3460-6

Evans, L., Fidelman, P., Hicks, C., Morgan, C., Perry, A. L., \& Tobin, R. (2016). Structural and psycho-social limits to climate change adaptation in the Great Barrier reef, 1-17. http://doi.org/10.1371/journal.pone.0150575

Füssel, H.-M., \& Klein, R. J. T. (2006). Climate Change Vulnerability Assessments: An Evolution of Conceptual Thinking. Climatic Change, 75(3), 301-329. http://doi.org/10.1007/s10584-006-0329-3

Gattuso, J.-P., Magnan, A., Billé, R., Cheung, W. W. L., Howes, E. L., Joos, F., ... Turley, C. (2015). Contrasting futures for ocean and society from different anthropogenic $\mathrm{CO} 2$ emissions scenarios. Science, 349(6243). http://doi.org/http://dx.doi.org/10.1126/science.aac4722

GCF. (2014). Decisions of the Board - Sixth Meeting of the Board, 19-21 February 2014. Retrieved from https://www.greenclimate.fund/documents/20182/24940/GCF_B.06_18__Decisions_of_the_Board_-_Sixth_Meeting_of_the_Board_19-21_February_2014.pdf

Gupta, J., Termeer, C., Klostermann, J., Meijerink, S., van den Brink, M., Jong, P., ... Bergsma, E. (2010). The Adaptive Capacity Wheel: a method to assess the inherent characteristics of institutions to enable the adaptive capacity of society. Environmental Science \& Policy, 13(6), 459-471. http://doi.org/10.1016/j.envsci.2010.05.006

Halpern, B. S., Longo, C., Hardy, D., McLeod, K. L., Samhouri, J. F., Katona, S. K., ... Zeller, D. (2012). An index to assess the health and benefits of the global ocean. Nature, 488(7413), 615-20. http://doi.org/10.1038/nature11397

Harrould-Kolieb, E., Hirshfield, M., \& Brosius, A. (2009). Major Emitters Among Hardest Hit by Ocean Acidification. Oceana, 12.

Hinkel, J. (2011). "Indicators of vulnerability and adaptive capacity": Towards a clarification of the science-policy interface. Global Environmental Change, 21(1), 198-208. http://doi.org/10.1016/j.gloenvcha.2010.08.002

Hobday, A. J., Cochrane, K., Downey-Breedt, N., Howard, J., Aswani, S., Byfield, V., ... van Putten, E. I. (2016). Planning adaptation to climate change in fast-warming marine regions with seafooddependent coastal communities. Reviews in Fish Biology and Fisheries, 26(2), 249-264. http://doi.org/10.1007/s11160-016-9419-0 
Hoegh-Guldberg, O., \& Bruno, J. F. (2010). The impact of climate change on the world's marine ecosystems. Science, 328(5985), 1523-1528. http://doi.org/10.1126/science.1189930

Hoegh-Guldberg, O., Cai, R., Poloczanska, E. S. S., Brewer, P. G. G., Sundby, S., Hilmi, K., ... Jung, S. (2014). The Ocean. In C. U. Press (Ed.), Climate Change 2014: Impacts, Adaptation, and Vulnerability. Part B: Regional Aspects. Contribution of Working Group II to the Fifth Assessment Report of the Intergovernmental Panel on Climate Change (pp. 1655-1731). Cambridge, United Kingdom and New York, NY, USA: Cambridge University Press. Retrieved from http://www.ipcc.ch/pdf/assessment-report/ar5/wg2/WGIIAR5-Chap30_FINAL.pdf

Huelsenbeck, M., \& Vorpahl, A. (2012). Ocean-Based Food Security Threatened in a High CO 2 World.

Hughes, S., Yau, A., Max, L., Petrovic, N., Davenport, F., Marshall, M., ... Cinner, J. E. (2012). A framework to assess national level vulnerability from the perspective of food security: The case of coral reef fisheries. Environmental Science and Policy, 23, 95-108. http://doi.org/10.1016/j.envsci.2012.07.012

Ionescu, C., Klein, R. J. T., Hinkel, J., Kavi Kumar, K. S., \& Klein, R. (2009). Towards a Formal Framework of Vulnerability to Climate Change. Environmental Modeling \& Assessment, 14(1), 1-16. http://doi.org/10.1007/s10666-008-9179-x

IPCC. (2012). Managing the Risks of Extreme Events and Disasters to Advance Climate Change Adaptation. (A. S. R. of W. G. I. and I. Of, T. F. S. Intergovernmental Panel on Climate Change [Field, C.B., V. Barros, S. K. A. D. Qin, D.J. Dokken, K.L. Ebi, M.D. Mastrandrea, K.J. Mach, G.-K. Plattner, \& and P. M. M. (eds. )]. M. Tignor, Eds.). Cambridge, UK and NY, NY: Cambridge University Press. http://doi.org/10.1017/CBO9781139177245

Klein, R. J. T. (2009). Identifying Countries that are Particularly Vulnerable to the Adverse Effects of Climate Change : An Academic or a Political Challenge ? Carbon \& Climate L. Rev., 3.

Lebel, L., Anderies, J. M., Campbell, B., Folke, C., Hatfield-Dodds, S., Hughes, T. P., \& Wilson, J. (2006). Governance and the Capacity to Manage Resilience in Regional Social-Ecological Systems. Ecology and Society, 11(1), art19. http://doi.org/10.5751/ES-01606-110119

Mastrandrea, M. D., Heller, N. E., Root, T. L., \& Schneider, S. H. (2010). Bridging the gap: linking climateimpacts research with adaptation planning and management. Climatic Change, 100(1), 87-101. http://doi.org/10.1007/s10584-010-9827-4

Mathis, J. T. T., Cooley, S. R. R., Lucey, N., Colt, S., Ekstrom, J., Hurst, T., ... Feely, R. a. A. (2015). Ocean acidification risk assessment for Alaska's fishery sector. Progress in Oceanography, 136, 71-91. http://doi.org/10.1016/j.pocean.2014.07.001

McGillivray, M. (1991). The human development index: Yet another redundant composite development indicator? World Development, 19(10), 1461-1468. http://doi.org/10.1016/0305-750X(91)90088-Y

Monnereau, I., Mahon, R., Mcconney, P., Nurse, L., Turner, R., \& Vall??s, H. (2017). The impact of methodological choices on the outcome of national-level climate change vulnerability assessments: An example from the global fisheries sector. Fish and Fisheries, (November 2016), 1-15. http://doi.org/10.1111/faf.12199

Mora, C., Myers, R. a, Coll, M., Libralato, S., Pitcher, T. J., Sumaila, R. U., ... Worm, B. (2009). Management 
effectiveness of the world's marine fisheries. PLoS Biology, 7(6), e1000131.

http://doi.org/10.1371/journal.pbio.1000131

O'Brien, K., Eriksen, S., Nygaard, L. P., \& Schjolden, A. (2007). Why different interpretations of vulnerability matter in climate change discourses. Climate Policy, 7(1), 73-88.

http://doi.org/10.3763/cpol.2007.0706

Oculi, N., \& Stephenson, S. R. (2018). Conceptualizing climate vulnerability : Understanding the negotiating strategies of Small Island Developing States. Environmental Science and Policy, 85(March), 72-80. http://doi.org/10.1016/j.envsci.2018.03.025

Oppenheimer, M., Campos, M., Warren, R., Birkmann, J., Luber, G., O’Neill, B., \& Takahashi, K. (2014). Emergent risks and key vulnerabilities. In : Climate Change 2014: Impacts, Adaptation, and Vulnerability. Part A: Global and Sectoral Aspects. Contribution of Working Group II to the Fifth Assessment Report of the Intergovernmental Panel on Climate Change (pp. 1039-1099). Cambridge, United Kingdom and New York, NY, USA: Cambridge University Press.

Pendleton, L., Comte, A., Langdon, C., Ekstrom, J. A., Cooley, R., Suatoni, L., ... Ritter, J. (2016). Coral Reefs and People in a High-CO 2 World: Where Can Science Make a Difference to People ? Plos One, 11(11), 1-21. http://doi.org/10.1371/journal.pone.0164699

Polsky, C., Neff, R., \& Yarnal, B. (2007). Building comparable global change vulnerability assessments: The vulnerability scoping diagram. Global Environmental Change, 17(3-4), 472-485. http://doi.org/10.1016/j.gloenvcha.2007.01.005

Preston, B. L., Yuen, E. J., \& Westaway, R. M. (2011). Putting vulnerability to climate change on the map: a review of approaches, benefits, and risks. Sustainability Science, 6(2), 177-202.

http://doi.org/10.1007/s11625-011-0129-1

Scheuer, S., Haase, D., \& Meyer, V. (2011). Exploring multicriteria flood vulnerability by integrating economic, social and ecological dimensions of flood risk and coping capacity: From a starting point view towards an end point view of vulnerability. Natural Hazards, 58(2), 731-751. http://doi.org/10.1007/s11069-010-9666-7

Schneider, S. Sarukhan, J. (2001). Overview of Impacts, Adaptation, and Vulnerability to Climate Change. In Climate Change 2001: Working Group II : Impacts, Adaptation and Vulnerability. Retrieved from www.grida.no/publications/other/ipcc_tar/

Schröter, D., Polsky, C., \& Patt, A. G. (2005). Assessing vulnerabilities to the effects of global change: an eight step approach. Mitigation and Adaptation Strategies for Global Change, 10, 573-596.

Sen, A. (1994). Human Development Index: Methodology and Measurement.

Smit, B., \& Pilifosova, O. (2003). Adaptation to climate change in the context of sustainable development and equity. Sustainable Development. Retrieved from https://www.vie.unu.edu/file/get/9995.pdf

Tango International in association with the Overseas Development Institute. (2015). First phase independent evaluation of the Adaptation Fund. Washington D.C.

Timmerman, P. (1981). Vulnerability, resilience, and the collapse of society. Institute for Environmental Studies. Toronto, Canada. Retrieved from 
http://www.ilankelman.org/miscellany/Timmerman1981.pdf

Tonmoy, F. N., El-zein, A., \& Hinkel, J. (2014). Assessment of vulnerability to climate change using indicators : a meta-analysis of the literature, 5(December). http://doi.org/10.1002/wcc.314

Tulloch, V. J. D., Tulloch, A. I. T., Visconti, P., Halpern, B. S., Watson, J. E. M., Evans, M. C., ... Possingham, H. P. (2015). Why do We map threats? Linking threat mapping with actions to make better conservation decisions. Frontiers in Ecology and the Environment, 13(2), 91-99. http://doi.org/10.1890/140022

Turner, B. L., Kasperson, R. E., Matson, P. A., McCarthy, J. J., Corell, R. W., Christensen, L., ... Schiller, A. (2003). A framework for vulnerability analysis in sustainability science. Proceedings of the National Academy of Sciences, 100(14), 8074-8079. http://doi.org/10.1073/pnas.1231335100

UNEP. (2014). The Adaptation Gap Report 2014. Nairobi, Kenya.

United Nations. The United Nations Framework Convention on Climate Change (UNFCCC) (1992).

Weatherdon, L. V., Magnan, A. K., Rogers, A. D., Sumaila, U. R., \& Cheung, W. W. L. Observed and projected impacts of climate change on marine fisheries, aquaculture, coastal tourism, and human health: an update, 3 Frontiers of Marine Science 48 (2016). Frontiers.

http://doi.org/10.3389/fmars.2016.00048

Weichselgartner, J. (2001). Disaster mitigation: the concept of vulnerability revisited. Disaster Prevention and Management: An International Journal, 10(2), 85-95. http://doi.org/10.1108/09653560110388609

Weichselgartner, J., \& Kasperson, R. (2010). Barriers in the science-policy-practice interface: Toward a knowledge-action-system in global environmental change research. Global Environmental Change, 20(2), 266-277. http://doi.org/10.1016/j.gloenvcha.2009.11.006

Wilby, R. L., \& Dessai, S. (2010). Robust adaptation to climate change. Weather, 65(7), 180-185. http://doi.org/10.1002/wea.543

Wolf, S., Hinkel, J., Bisaro, A., \& Klein, R. J. T. (2012). Clarifying vulnerability definitions and assessments using formalisation, (018476), 54-70. http://doi.org/10.1108/17568691311299363

Wolff, N. H., Donner, S. D., Cao, L., Iglesias-Prieto, R., Sale, P. F., \& Mumby, P. J. (2015). Global inequities between polluters and the polluted: climate change impacts on coral reefs. Global Change Biology, 21(11), 3982-3994. http://doi.org/10.1111/gcb.13015 
Figure 1. Conceptual frameworks of vulnerability used by the IPCC in (a) the Third assessment report of 2001 and (b) the Fifth assessment report of 2014. Sources: (a) "Places of adaptation in the climate change issue" (Schneider and Sarukhan, 2001, p.90) (b) "Schematic of the interaction among the physical climate system, exposure, and vulnerability producing risk" (Oppenheimer et al., 2014, p.1046).

Figure 2. Contributing factors to potential impacts and vulnerability (adapted from lonescu et al., 2009; Schneider and Sarukhan, 2001). Exposure, sensitivity and hazard event (bold) are predictive and speculative outcomes that lead to potential impacts. Vulnerability is the combination of potential impacts and adaptive capacity. *Adaptive capacity is highly context specific.

Figure 3. 2-tier strategy to conduct assessments vulnerability assessments at different scales. 
Table 1. Objectives, definitions of vulnerability, and formulae used in eight global reports. (V) vulnerability, (E) exposure, (S) Sensitivity or dependence, (CC) coping capacity, (AC) adaptive capacity, (OHI) Ocean Health Index, (C) current status, (T) trend, (P) pressure, (Re) resilience

\begin{tabular}{|c|c|c|c|c|c|c|c|c|}
\hline & $\begin{array}{l}\text { Harrould-Kolieb } \\
\text { et al., } 2009\end{array}$ & Allison et al., 2009 & Burke et al., 2011 & $\begin{array}{c}\text { Huelsenbeck \& } \\
\text { Vorpahl, } 2012 \\
\end{array}$ & $\begin{array}{c}\text { Hughes et al., } \\
2012 \\
\end{array}$ & Beck, 2014 & Barange et al., 2014 & $\begin{array}{c}\text { Halpern et al., } \\
2012 \\
\end{array}$ \\
\hline Objectives & $\begin{array}{l}\text { "evaluated the } \\
\text { likely vulnerability } \\
\text { of different } \\
\text { countries to } \\
\text { continued ocean } \\
\text { acidification" p.1 }\end{array}$ & $\begin{array}{l}\text { "we provide an } \\
\text { indicator-based analysis } \\
\text { of the relative } \\
\text { vulnerabilities of } 132 \\
\text { countries to climate } \\
\text { change impacts on } \\
\text { fisheries." p.175 }\end{array}$ & $\begin{array}{l}\text { "developed a new, } \\
\text { detailed assessment of the } \\
\text { status of and threats to } \\
\text { the world's coral reefs. } \\
\text { This information is } \\
\text { intended to raise } \\
\text { awareness about the } \\
\text { location and severity of } \\
\text { threats to coral reefs. } \\
\text { These results can also } \\
\text { catalyze opportunities for } \\
\text { changes in policy and } \\
\text { practice that could } \\
\text { safeguard coral reefs and } \\
\text { the benefits they provide } \\
\text { to people for future } \\
\text { generations." p.1 }\end{array}$ & $\begin{array}{l}\text { "ranks nations } \\
\text { based on the } \\
\text { seafood security } \\
\text { hardships they } \\
\text { may experience } \\
\text { by the middle of } \\
\text { this century due } \\
\text { to changing ocean } \\
\text { conditions from } \\
\text { climate change } \\
\text { and ocean } \\
\text { acidification." p.2 }\end{array}$ & $\begin{array}{l}\text { "develop a } \\
\text { framework to } \\
\text { identify most } \\
\text { vulnerable regions, } \\
\text { the mechanisms } \\
\text { creating this } \\
\text { vulnerability, and } \\
\text { the potential policy } \\
\text { interventions that } \\
\text { may this reduce } \\
\text { food security } \\
\text { vulnerability." p.96 }\end{array}$ & $\begin{array}{l}\text { "1) examines the risks } \\
\text { that nations face from } \\
\text { vulnerability and } \\
\text { exposure to coastal } \\
\text { hazards; } 2 \text { ) identifies } \\
\text { where environmental } \\
\text { degradation contributes } \\
\text { to these risks; and 3) } \\
\text { explores where } \\
\text { environmental solutions } \\
\text { can contribute to risk } \\
\text { reduction." p.2 }\end{array}$ & $\begin{array}{l}\text { "develop and link } \\
\text { models of physical, } \\
\text { biological and human } \\
\text { responses to climate } \\
\text { change in } 67 \text { marine } \\
\text { national exclusive } \\
\text { economic zones, which } \\
\text { yield approximately } 60 \% \\
\text { of global fish catches, to } \\
\text { project climate change } \\
\text { yield impacts in } \\
\text { countries with different } \\
\text { dependencies on marine } \\
\text { fisheries" p.211 }\end{array}$ & $\begin{array}{l}\text { "developed and } \\
\text { implemented a } \\
\text { systematic approach } \\
\text { for measuring } \\
\text { overall condition of } \\
\text { marine ecosystems } \\
\text { that treats nature } \\
\text { and people as } \\
\text { integrated parts of a } \\
\text { healthy system." p.1 }\end{array}$ \\
\hline $\begin{array}{l}\text { Definition of } \\
\text { vulnerability }\end{array}$ & $\begin{array}{l}\text { "based on the } \\
\text { magnitude of their } \\
\text { fish and shellfish } \\
\text { catch, their level of } \\
\text { seafood } \\
\text { consumption, the } \\
\text { percentage of coral } \\
\text { reefs within their } \\
\text { exclusive economic } \\
\text { zones (EEZ) and the } \\
\text { projected level of } \\
\text { ocean acidification } \\
\text { in their coastal } \\
\text { waters in 2050." p.1 }\end{array}$ & $\begin{array}{l}\text { "a combination of the } \\
\text { extrinsic exposure of } \\
\text { groups or individuals or } \\
\text { ecological systems to a } \\
\text { hazard, such as climate } \\
\text { change, their intrinsic } \\
\text { sensitivity to the hazard, } \\
\text { and their lack of capacity } \\
\text { to modify exposure to, } \\
\text { absorb, and recover } \\
\text { from losses stemming } \\
\text { from the hazard, and to } \\
\text { exploit new } \\
\text { opportunities that arise } \\
\text { in the process of } \\
\text { adaptation" p.175 }\end{array}$ & $\begin{array}{l}\text { "We represent } \\
\text { vulnerability as the } \\
\text { combination of three } \\
\text { components: exposure to } \\
\text { reef threats, dependence } \\
\text { on reef ecosystem } \\
\text { services (that is, social and } \\
\text { economic sensitivity to } \\
\text { reef loss), and the capacity } \\
\text { to adapt to the potential } \\
\text { impacts of reef loss." p.66 }\end{array}$ & $\begin{array}{l}\text { "combining each } \\
\text { nation's exposure } \\
\text { to climate change } \\
\text { and ocean } \\
\text { acidification, its } \\
\text { dependence on } \\
\text { and consumption } \\
\text { of fish and } \\
\text { seafood and its } \\
\text { level of adaptive } \\
\text { capacity based on } \\
\text { several } \\
\text { socioeconomic } \\
\text { factors." p.2 }\end{array}$ & $\begin{array}{l}\text { "degree to which a } \\
\text { country is } \\
\text { susceptible to a } \\
\text { decline in coral reef } \\
\text { fisheries as a food } \\
\text { source and is ability } \\
\text { to respond to the } \\
\text { decline." p.96 }\end{array}$ & $\begin{array}{l}\text { "Risk is a function of } \\
\text { exposure of people and } \\
\text { assets to a geophysical } \\
\text { hazard (e.g., flood) and } \\
\text { the social vulnerability } \\
\text { of communities. The } \\
\text { three components of } \\
\text { vulnerability are } \\
\text { susceptibility, coping } \\
\text { capacity and adaptive } \\
\text { capacity." p.2 }\end{array}$ & $\begin{array}{l}\text { "depends on three key } \\
\text { elements: exposure to } \\
\text { the physical effects of } \\
\text { climate change; } \\
\text { economic and social } \\
\text { dependency on the } \\
\text { changing variable(s); and } \\
\text { adaptive capacity to the } \\
\text { changes." p. } 214\end{array}$ & $N / A$ \\
\hline $\begin{array}{l}\text { Formulae } \\
\text { for } \\
\text { vulnerability }\end{array}$ & $V=E+S$ & $V=f(E, S, A C)$ & $V=E^{*} S^{*} A C$ & $V=E+S-A C$ & $V=E+S-A C$ & $V=S+C C+A C ;$ Risk $=E^{*} V$ & $\mathrm{I}=\mathrm{E}^{*} \mathrm{~S}$ & $\mathrm{OHI}=\mathrm{f}(\mathrm{C}, \mathrm{T}, \mathrm{P}, \mathrm{Re})$ \\
\hline
\end{tabular}



Table 2. Top 10 countries at risk from climate change impacts on the coasts and ocean, extracted from eight global reports and listed regardless of their original rank. In red, countries found in four of the reports, in orange, countries found in three of the reports, in yellow, countries found in two reports, in white countries found in only one of the reports. ${ }^{*}$ Burke et al. (2011) only identifies 9 countries as highly vulnerable

\begin{tabular}{|c|c|c|c|c|c|c|c|c|}
\hline \multicolumn{9}{|c|}{ Vulnerability Ranking } \\
\hline \multirow{11}{*}{$\begin{array}{l}\text { Top } 10 \\
\text { countries }\end{array}$} & $\begin{array}{l}\text { Burke et } \\
\text { al., 2011* }\end{array}$ & $\begin{array}{l}\text { Hughes et } \\
\text { al., } 2012\end{array}$ & $\begin{array}{l}\text { Barange et } \\
\text { al., } 2014\end{array}$ & $\begin{array}{c}\text { Halpern et al., } \\
2012\end{array}$ & $\begin{array}{c}\text { Huelsenbeck \& } \\
\text { Vorpahl, } 2012\end{array}$ & Beck, 2014 & $\begin{array}{c}\text { Allison et al., } \\
2009\end{array}$ & $\begin{array}{c}\text { Harrould- } \\
\text { Kolieb et al., } \\
2009\end{array}$ \\
\hline & Philippines & Philippines & Sierra Leone & Sierra Leone & Sierra Leone & Philippines & Sierra Leone & Philippines \\
\hline & Kiribati & Indonesia & Ivory Coast & Ivory Coast & Kiribati & Kiribati & DR Congo & Indonesia \\
\hline & Indonesia & Liberia & Liberia & Liberia & Comoros & Fiji & Mozambique & Australia \\
\hline & Comoros & Ivory Coast & Senegal & DR Congo & Mozambique & Vanuatu & Senegal & France \\
\hline & Fiji & Tanzania & Togo & Haiti & Togo & Antigua \& Barbuda & Angola & Japan \\
\hline & Haiti & Cambodia & Benin & Dominica & Cook Islands & Bangladesh & Mali & Malaysia \\
\hline & Vanuatu & Cameroon & Gambia & East Timor & Eritrea & Brunei Durassalam & Mauritania & Netherlands \\
\hline & Grenada & Egypt & Ghana & Libya & Madagascar & Saint Kitts \& Nevis & Niger & New Zealand \\
\hline & Tanzania & Honduras & Guinea-Bissau & Nicaragua & Pakistan & Seychelles & Peru & $\begin{array}{l}\text { United } \\
\text { Kingdom }\end{array}$ \\
\hline & & Kenya & Iceland & $\begin{array}{c}\text { St. Vincent \& } \\
\text { Grenadines }\end{array}$ & Thailand & Tonga & $\begin{array}{l}\text { Russian } \\
\text { Federation }\end{array}$ & United States \\
\hline
\end{tabular}


Table 3. Adaptive capacity metrics extracted from eight global vulnerability assessments reports and categorized according to the five domains described in (Cinner et al., 2018). Compared to Tables $1 \& 2$, Barange et al. (2014) and Harrould-Kolieb et al. (2009) do not use adaptive capacity metrics in their vulnerability index and therefore are not presented here

\begin{tabular}{|c|c|c|c|c|c|c|}
\hline Categories & Burke et al., 2011 & Hughes et al., 2012 & $\begin{array}{l}\text { Halpern et al., } \\
2012\end{array}$ & $\begin{array}{l}\text { Huelsenbeck \& } \\
\text { Vorpahl, } 2012\end{array}$ & Beck, 2014 & Allison et al., 2009 \\
\hline \multirow[t]{6}{*}{ Assets } & $\begin{array}{c}\text { GDP + remittances per } \\
\text { capita }\end{array}$ & GDP per capita & $\begin{array}{c}\text { Global } \\
\text { Competitivenes } \\
\text { s Index } \\
\end{array}$ & GDP per capita & $\begin{array}{l}\text { Public health } \\
\text { expenditure }\end{array}$ & Total GDP \\
\hline & Average life expectancy & $\begin{array}{c}\% \text { of population } \\
\text { with access to } \\
\text { sanitation } \\
\end{array}$ & $\begin{array}{l}\text { Access to } \\
\text { artisanal fishing }\end{array}$ & $\begin{array}{c}\% \text { of the } \\
\text { population } \\
\text { undernourished } \\
\end{array}$ & Life expectancy at birth & $\begin{array}{l}\text { Healthy life } \\
\text { expectancy }\end{array}$ \\
\hline & & Reef area per capita & $\begin{array}{l}\text { Ecological } \\
\text { integrity }\end{array}$ & $\begin{array}{c}\text { Population } \\
\text { growth rate } \\
2012-2050 \\
\end{array}$ & $\begin{array}{l}\text { Private health } \\
\text { expenditure }\end{array}$ & \\
\hline & & & & & $\begin{array}{c}\text { \# physicians and \# } \\
\text { hospital beds per } 10000 \\
\text { inhabitants }\end{array}$ & \\
\hline & & & & & Water resources & \\
\hline & & & & & Fish stock status & \\
\hline \multirow[t]{2}{*}{ Flexibility } & $\begin{array}{l}\% \text { of population within } \\
25 \mathrm{~km} \text { of market centers }\end{array}$ & $\begin{array}{c}\text { Trade balance } \\
\text { standardized by } \\
\text { GDP per capita } \\
\end{array}$ & Sector diversity & & $\begin{array}{l}\text { Livelihood diversity } \\
\text { index }\end{array}$ & \\
\hline & $\begin{array}{l}\text { Agricultural land area } \\
\text { per agricultural worker }\end{array}$ & GINI index & & & Insurances & \\
\hline \multirow[t]{6}{*}{ Organization } & $\begin{array}{l}\text { Fisheries subsidies that } \\
\text { encourage resource } \\
\text { conservation and } \\
\text { management, as a \% of } \\
\text { fisheries value }\end{array}$ & $\begin{array}{c}\text { Fisheries } \\
\text { management } \\
\text { effectiveness }\end{array}$ & $\begin{array}{c}\text { Fisheries } \\
\text { management } \\
\text { effectiveness }\end{array}$ & & $\begin{array}{c}\text { Fisheries management } \\
\text { effectiveness }\end{array}$ & Political stability \\
\hline & $\begin{array}{l}\text { Worldwide Governance } \\
\text { indicator }\end{array}$ & $\begin{array}{l}\text { Government } \\
\text { effectiveness index }\end{array}$ & $\begin{array}{c}\text { Worldwide } \\
\text { Governance } \\
\text { indicator }\end{array}$ & & $\begin{array}{l}\text { Corruption perception } \\
\text { index }\end{array}$ & $\begin{array}{l}\text { Government } \\
\text { effectiveness }\end{array}$ \\
\hline & & $\begin{array}{c}\text { Score indicating } \\
\text { mention of fisheries } \\
\text { management in } \\
\text { national-level policy } \\
\text { documents } \\
\end{array}$ & $\begin{array}{c}\text { Marine } \\
\text { Protected areas }\end{array}$ & & Failed states index & Regulatory quality \\
\hline & & & $\begin{array}{c}\text { Management } \\
\text { effectiveness of } \\
\text { artisanal fishing } \\
\end{array}$ & & $\begin{array}{l}\text { Agricultural } \\
\text { management }\end{array}$ & Rule of law \\
\hline & & & $\begin{array}{c}\text { Mariculture } \\
\text { sustainability } \\
\text { Index } \\
\end{array}$ & & $\begin{array}{c}\text { Biodiversity and habitat } \\
\text { protection }\end{array}$ & Corruption \\
\hline & & & & & Forest management & \\
\hline \multirow[t]{3}{*}{ Learning } & Adult literacy rate & Adult literacy rate & & & Adult literacy rate & Adult literacy rate \\
\hline & $\begin{array}{c}\text { Combined ratio of } \\
\text { enrollment in primary, } \\
\text { secondary, and tertiary } \\
\text { education }\end{array}$ & $\begin{array}{l}\text { Scientific } \\
\text { robustness }\end{array}$ & & & $\begin{array}{l}\text { Gender parity in } \\
\text { education }\end{array}$ & $\begin{array}{l}\text { School enrolment \% } \\
\text { in primary, } \\
\text { secondary and } \\
\text { tertiary education }\end{array}$ \\
\hline & & & & & Combined gross school & \\
\hline
\end{tabular}




\begin{tabular}{|c|l|l|l|l|l|l|}
\hline & & & & & enrollment & \\
\hline Agency & & & $\begin{array}{c}\text { CBD survey and } \\
\text { signatories }\end{array}$ & & $\begin{array}{c}\text { \% female } \\
\text { resentative in } \\
\text { Parliament }\end{array}$ & $\begin{array}{c}\text { Voice and } \\
\text { accountability }\end{array}$ \\
\hline & & & $\begin{array}{c}\text { CITES } \\
\text { signatories }\end{array}$ & & \\
\hline
\end{tabular}




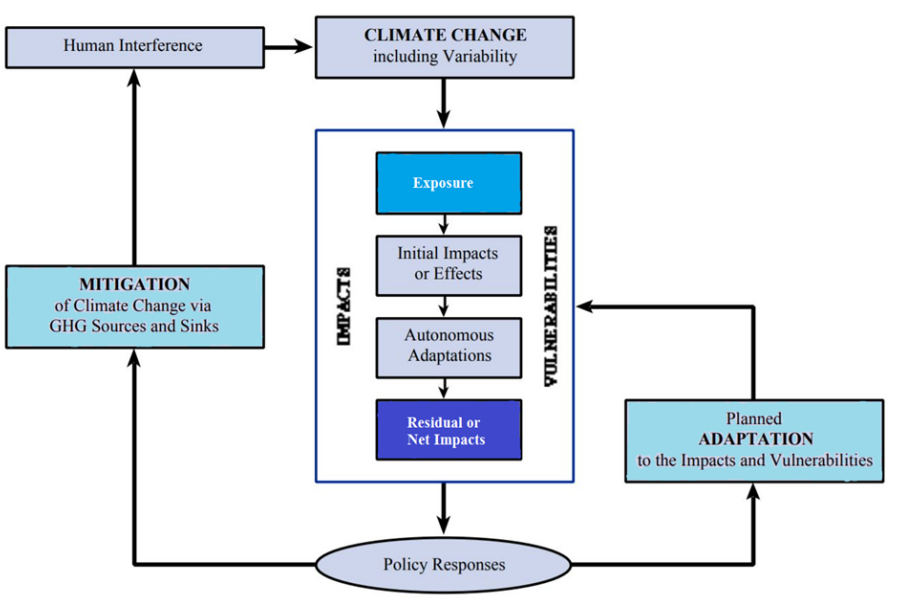

(a)

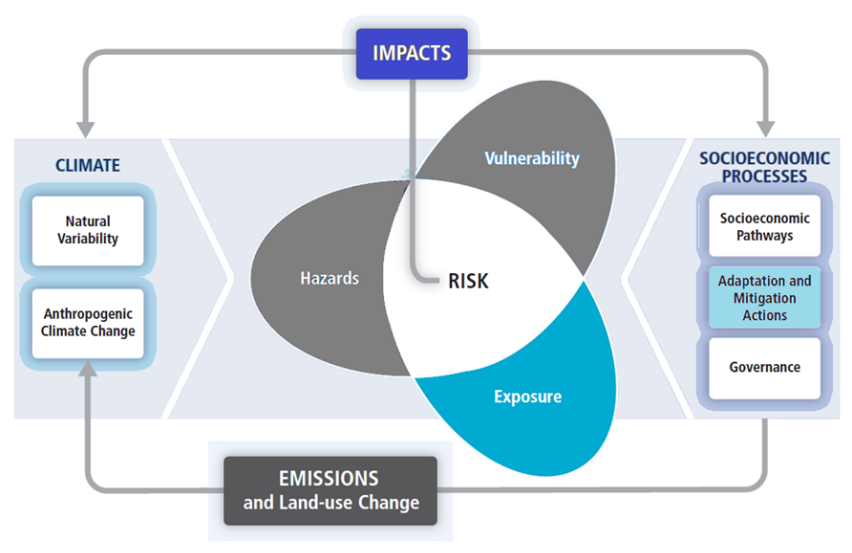

(b)

Figure 1. Conceptual frameworks of vulnerability used by the IPCC in (a) the Third assessment report of 2001 and (b) the Fifth assessment report of 2014. Sources: (a) "Places of adaptation in the climate change issue" (Schneider and Sarukhan, 2001, p.90) (b) "Schematic of the interaction among the physical climate system, exposure, and vulnerability producing risk" (Oppenheimer et al., 2014, p.1046). 


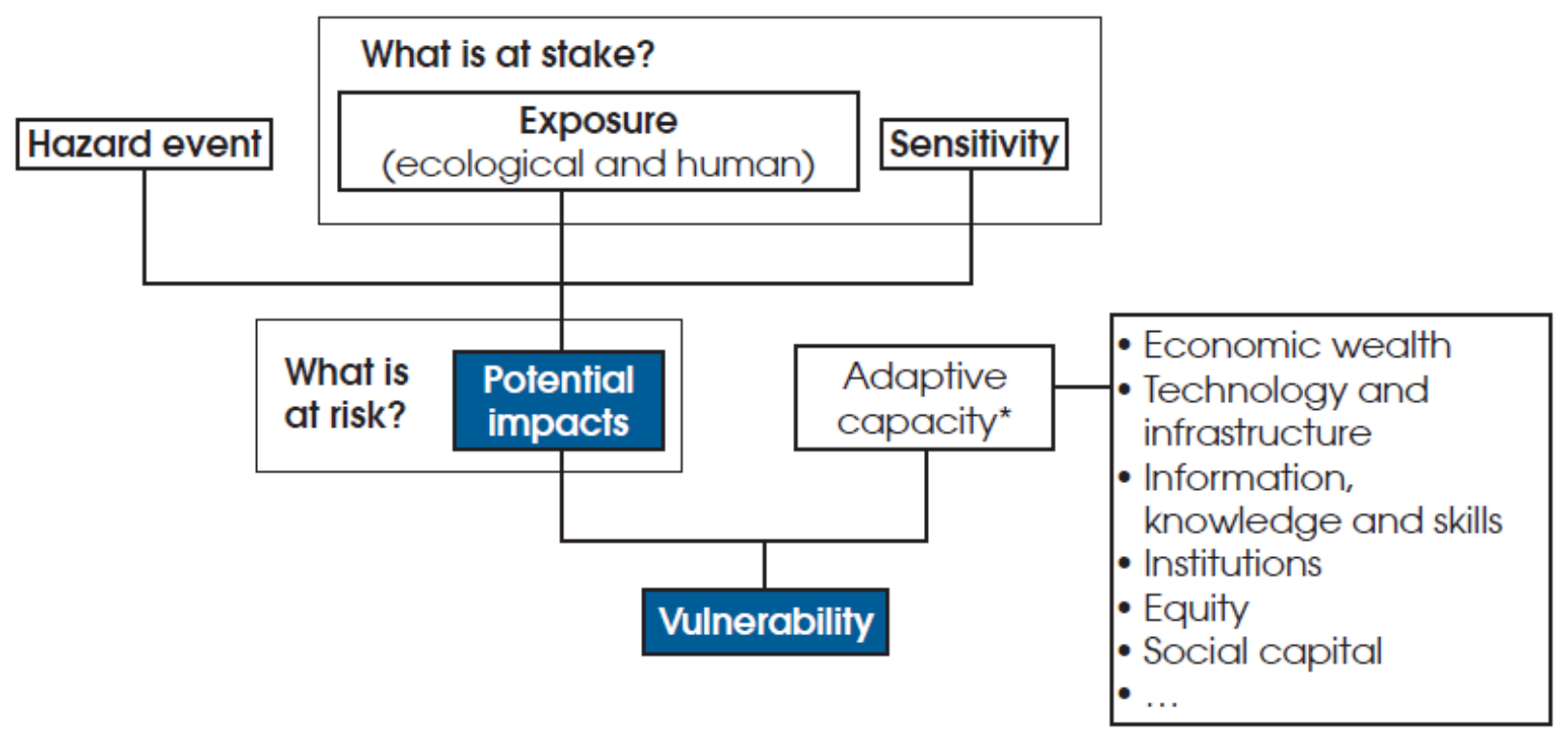

Figure 2. Contributing factors to potential impacts and vulnerability (adapted from lonescu et al., 2009; Schneider and Sarukhan, 2001). Exposure, sensitivity and hazard event (bold) are predictive and speculative outcomes that lead to potential impacts. Vulnerability is the combination of potential impacts and adaptive capacity. *Adaptive capacity is highly context specific. 


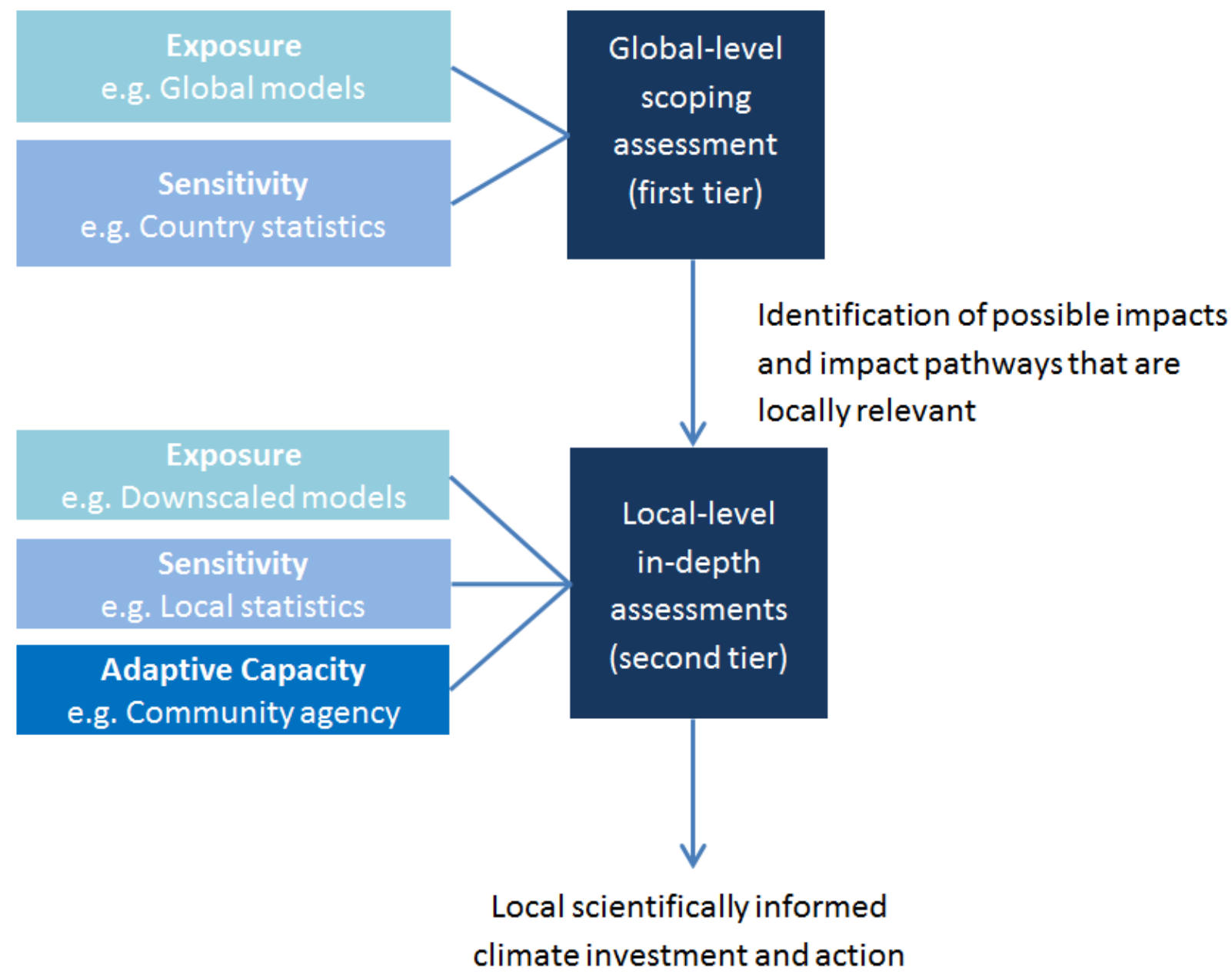

Figure 3. 2-tier strategy to conduct assessments vulnerability assessments at different scales. 